\title{
PENGARUH PROFITABILITAS DAN KAPITALISASI PASAR TERHADAP NILAI EMITEN JAKARTA ISLAMIC INDEX
}

\author{
Raden Arfan Rifqiawan
}

\begin{abstract}
Abstrak
Tulisan ini meneliti pengaruh antara Return on Assets (ROA) sebagai proksi dari profitabilitas dan kapitalisasi pasar terhadap Tobin's Q sebagai proksi dari nilai emiten. Tujuan penelitian adalah untuk menemukan bukti empiris tentang pengarub profitabilitas dan kapitalisasi pasar terhadap nilai emiten. Sampel dalam penelitian ini adalah emiten Jakarta Islamic Index (II) yang terdaftar dalam Indonesia Stock Exchange (IDX) dalam rentang tabun 2012-2014. Sampel penelitian adalab sebanyak 21 perusabaan dengan 63 kali pengamatan. Analisis data menggunakan analisis regresi linear berganda. Hasil penelitian dengan analisis regresi linear berganda menunjuk.kan bahwa profitabilitas berpengaruh signifikan terhadap nilai emiten. Hal ini ditunjukkan dengan taraf signifikansi dari hasil uji statistik t sebesar 0,000 (<0,05). Sedangkan kapitalisasi pasar tidak berpengaruh secara signifikan terhadap nilai emiten yang ditunjukean dengan taraf signifikansi sebesar 0,195 (>0,05). Namun secara simultan profitabilitas dan kapitalisasi pasar berpengaruh signifikan terhadap nilai emiten. Hal ini diketabui dari hasil uji statistik F, taraf signifikansinya sebesar 0,000 (<0,05). Nilai Koefisien Determinasi sebesar 0,653 menunjukkan bahwa model regresinya sudab baik karena kemampuan variabel bebas dalam menjelaskan variabel terikat sebesar 65,3\%. Sisanya sebesar $34,7 \%$ dijelaskan oleh variabel di luar penelitian.
\end{abstract}

Kata Kunci: $R O A$, Kapitalisasi Pasar, Tobin's Q.

\section{Pendahuluan}

Dalam berinvestasi di pasar modal, investor akan mempertimbangkan beberapa faktor, antara lain profitabilitas dan kapitalisasi pasar. Profitabilitas adalah kemampuan perusahaan dalam menghasilkan laba dalam periode tertentu. Profitabilitas diukur dengan rasio profitabilitas seperti ROA, ROE, 
Pengaruh Profitabliitas dan Kapitalisasi Pasar...

Earning per Share, Gross Profit Margin, dll. ${ }^{1}$ Sedangkan kapitalisasi pasar adalah nilai pasar dari saham yang diterbitkan (outstanding share) suatu emiten. ${ }^{2}$ Kapitalisasi pasar didapatkan dari mengalikan jumlah saham yang beredar dengan harga saham penutupannya. Besar atau tidaknya perusahaan di bursa saham dapat dilihat dari kapitalisasi pasarnya.

Profitabilitas perusahaan merupakan kondisi fundamental perusahaan yang dapat dilihat dari perhitungan rasio-rasio keuangannya, sedangkan kapitalisasi pasar menunjukkan jumlah rupiah dari seluruh saham yang terjual di bursa yang nilainya akan mengikuti trend pasar yang dapat diramalkan menggunakan alat analisis teknikal. ${ }^{3}$

Nilai emiten dalam penelitian ini didefinisikan sebagai nilai pasar, seperti halnya penelitian yang pernah dilakukan oleh Nurlela dan Islahuddin, ${ }^{4}$ karena nilai emiten dapat memberikan kemakmuran pemegang saham secara maksimum apabila harga saham perusahaan meningkat. Semakin tinggi harga saham, maka makin tinggi kemakmuran pemegang saham. Untuk mencapai nilai emiten umumnya para pemodal menyerahkan pengelolaannya kepada para professional. Para profesional diposisikan sebagai manajer ataupun komisaris.

Samuel dalam Nurlela dan Islahuddin menjelaskan bahwa enterprise value (EV) atau dikenal juga sebagai firm value (nilai emiten) merupakan konsep penting bagi investor, karena merupakan indikator bagi pasar menilai emiten secara keseluruhan. ${ }^{5}$ Sedangkan Wahyudi dalam Nurlela dan Islahuddin menyebutkan bahwa nilai emiten merupakan harga yang bersedia dibayar oleh calon pembeli andai perusahaan tersebut dijual. ${ }^{6}$ Dalam penilaian perusahaan terkandung unsur proyeksi, asuransi, perkiraan, dan judgment. Ada beberapa konsep dasar penilaian yaitu : nilai ditentukan untuk suatu waktu

\footnotetext{
${ }^{1}$ Jumingan, Analisis Laporan Kenangan, Jakarta: Bumi Aksara, 2005, hlm. 122 hlm. 41

${ }^{2}$ Sapto Rahardjo, Kiat Membangun Aset Kekayaan, Jakarta: PT. Elex Media Komputindo, 2006,

3 A. Fauzi, dkk., Aplikasi Excel dalam Finansial Terapan, Jakarta: PT.ELex Media Komputindo, 2004, hlm. 145

${ }^{4}$ Rika Nurlela dan dan Islahudin, "Pengaruh Corporate Social Responsibility terhadap Nilai Emiten dengan Prosentase Kepemilikan Manajemen sebagai Variabel Moderating", Simposium Nasional Akuntansi XI Pontianak, 2008, hlm. 7

${ }^{5}$ Ibid

${ }^{6}$ Ibid
} 
atau periode tertentu; nilai harus ditentukan pada harga yang wajar; penilaian tidak dipengaruhi oleh kelompok pembeli tertentu. Secara umum banyak metode dan teknik yang telah dikembangkan dalam penilaian perusahaan, di antaranya adalah : a) pendekatan laba antara lain metode rasio tingkat laba atau price earning ratio, metode kapitalisasi proyeksi laba; b) pendekatan arus kas antara lain metode diskonto arus kas; c) pendekatan dividen antara lain metode pertumbuhan dividen; d) pendekatan aktiva antara lain metode penilaian aktiva; e) pendekatan harga saham; f) pendekatan economic value added.

Pada dasarnya tujuan manajemen keuangan adalah memaksimumkan nilai emiten. Akan tetapi di balik tujuan tersebut masih terdapat konflik antara pemilik perusahaan dengan penyedia dana sebagai kreditur. Jika perusahaan berjalan lancar, maka nilai saham perusahaan akan meningkat, sedangkan nilai hutang perusahaan dalam bentuk obligasi tidak terpengaruh sama sekali. Jadi dapat disimpulkan bahwa nilai dari saham kepemilikan bisa merupakan indeks yang tepat untuk mengukur tingkat efektifitas perusahaan. Berdasarkan alasan itulah, maka tujuan manajemen keuangan dinyatakan dalam bentuk maksimalisasi nilai saham kepemilikan perusahaan, atau memaksimalisasikan harga saham. Tujuan memaksimumkan harga saham tidak berarti bahwa para manajer harus berupaya mencari kenaikan nilai saham dengan mengorbankan para pemegang obligasi.

Salah satu alternatif yang digunakan dalam menilai nilai emiten adalah dengan menggunakan Tobin's Q. Rasio ini dikembangkan oleh James Tobin. Rasio ini merupakan konsep yang berharga karena menunjukkan estimasi pasar keuangan saat ini tentang nilai hasil pengembalian dari setiap dolar investasi incremental. Jika rasio Q di atas satu, ini menunjukkan bahwa investasi dalam aktiva menghasilkan laba yang memberikan nilai yang lebih tinggi daripada pengeluaran investasi, hal ini akan merangsang investasi baru. Jika rasio Q di bawah satu, investasi dalam aktiva tidaklah menarik. Rasio Q merupakan ukuran yang lebih teliti tentang seberapa efektif manajemen memanfaatkan sumber-sumber daya ekonomi dalam kekuasaannya. Penelitian yang dilakukan oleh Herawaty, menunjukkan bagaimana rasio Q dapat diterapkan pada masing- masing perusahaan. Mereka menemukan bahwa beberapa perusahaan dapat mempertahankan rasio $Q$ yang lebih besar dari satu. Teori ekonomi mengatakan bahwa rasio $Q$ yang lebih besar dari satu 
Pengaruh Profitabliitas dan Kapitalisasi Pasar...

akan menarik arus sumber daya dan kompetisi baru sampai rasio Q mendekati satu. Variabel ini diberi simbol Q.

Adapun tujuan dari penelitian ini adalah untuk mengetahui pengaruh parsial maupun simultan dari profitabilitas dan kapitalisasi pasar terhadap nilai emiten yang tercatat dalam Jakarta Islamic Index (JII) di Bursa Efek Indonesia.

\section{Metodologi}

Variabel yang digunakan dalam penelitian ini terdiri dari variabel independen dan variabel dependen. Variabel independen adalah variabel yang menjelaskan atau mempengaruhi variabel yang lain. Variabel independen dalam penelitian ini adalah profitabilitas dan kapitalisasi pasar. Sedangkan variabel dependen adalah variabel yang dijelaskan atau dipengaruhi oleh variabel independen. Variabel dependen pada penelitian ini adalah nilai emiten.

Profitabilitas yang merupakan variabel independen dalam penelitian ini, disimbolkan dengan $\left(\mathrm{X}_{1}\right)$. Profitabilitas didekati dengan Return on Assets (ROA) yang didapatkan dari laporan keuangan tahunan perusahaan JII, selama periode penelitian. ROA menunjukkan perbandingan net income dan total assets perusahaan. Alasan dipilihnya (ROA) sebagai proksi profitabilitas, karena rasio tersebut merupakan indikator penting dari laporan keuangan yang memiliki berbagai kegunaan. Rasio ROA digunakan untuk mengukur kemampuan manajemen perusahaan dalam memperoleh keuntungan (laba) secara keseluruhan. Semakin besar ROA suatu perusahaan, semakin besar pula tingkat keuntungan yang dicapai perusahaan tersebut dan semakin baik pula posisi perusahaan tersebut dari segi penggunaan aktiva. Laba pada umumnya dipakai sebagai suatu dasar pengambilan keputusan investasi dan prediksi untuk meramalkan perubahan laba yang akan datang. Investor mengharapkan dana yang diinvestasikan ke dalam perusahaan akan memperoleh tingkat pengembalian yang tinggi sehingga laba yang diperoleh jadi tinggi pula.

Rumus ROA :

$$
\text { Return on Asset }=\frac{\text { Profit Before Income Tax }}{\text { Total Aktiva }}
$$

Nilai emiten disimbolkan dengan (Y). Salah satu alternatif yang 
digunakan dalam menilai nilai emiten adalah dengan menggunakan Tobin's Q. Rasio ini dikembangkan oleh James Tobin. Rasio ini merupakan konsep yang berharga karena menunjukkan estimasi pasar keuangan saat ini tentang nilai hasil pengembalian dari setiap dolar investasi incremental. Jika rasio Q di atas satu, ini menunjukkan bahwa investasi dalam aktiva menghasilkan laba yang memberikan nilai yang lebih tinggi daripada pengeluaran investasi, hal ini akan merangsang investasi baru. Jika rasio $Q$ di bawah satu, investasi dalam aktiva tidaklah menarik.

Rasio Q merupakan ukuran yang lebih teliti tentang seberapa efektif manajemen memanfaatkan sumber-sumber daya ekonomi dalam kekuasaannya. Penelitian yang dilakukan oleh Herawaty, menunjukkan bagaimana rasio Q dapat diterapkan pada masing- masing perusahaan. Mereka menemukan bahwa beberapa perusahaan dapat mempertahankan rasio $Q$ yang lebih besar dari satu. Teori ekonomi mengatakan bahwa rasio Q yang lebih besar dari satu akan menarik arus sumber daya dan kompetisi baru sampai rasio Q mendekati satu. Variabel ini diberi simbol Q. Variabel ini telah digunakan oleh Herawaty . Penghitungannya menggunakan rumus. ${ }^{7}$

$$
\mathrm{Q}=\frac{(E M V+D)}{(E B V+D)}
$$

Dimana :

Q $\quad=$ Nilai emiten

$\mathrm{EMV}=$ Nilai pasar ekuitas $(\mathrm{EMV}=$ closing price $\mathrm{x}$ jumlah saham yang beredar)

$\mathrm{D}=$ Nilai buku dari total hutang

EBV = Nilai buku dari total ekuitas

Populasi dari penelitian ini adalah perusahaan-perusahaan atau emiten yang tercatat dalam JII di BEI. Penelitian ini menggunakan periode penelitian tahun 2012, 2013 dan 2014. Pemilihan sampel dilakukan dengan menggunakan metode purposive sampling dengan tujuan untuk mendapatkan sampel yang representatif sesuai dengan kriteria yang ditentukan. Adapun

\footnotetext{
7 Vinolla Herawaty, "Peran Praktek Corporate Governance sebagai Moderating Variable dari Pengaruh Earnings Management terhadap Nilai emiten", Jurnal Akuntansi dan Kenangan, Vol. 10, No. 2, 2008, hlm. 97-108
} 
Pengaruh Profitabliitas dan Kapitalisasi Pasar...

kriteria sampel yang akan digunakan yaitu :

1. Perusahaan yang masuk JII di BEI secara berturut-turut untuk tahun 2012, 2013 dan 2014.

2. Menyediakan laporan tahunan lengkap pada akhir tahun 2012, 2013 dan 2014.

3. Memiliki data yang lengkap terkait dengan variabel-variabel yang digunakan dalam penelitian.

Jenis data yang digunakan dalam penelitian ini adalah data sekunder yaitu data kuantitatif yang diperoleh dari pojok BEI FEBI UIN Walisongo. Sedangkan data yang digunakan dalam penelitian ini adalah laporan tahunan perusahaan untuk periode 2012, 2013 dan 2014 pada perusahaan-perusahaan JII yang terdaftar di BEI, Pengumpulan data dilakukan dengan cara menelusuri laporan tahunan yang terpilih menjadi sampel.

Uji normalitas bertujuan untuk menguji apakah dalam model regresi, variabel pengganggu atau residual memiliki distribusi normal. ${ }^{8}$ Ada dua cara untuk mengetahui apakah residual terdistribusi normal atau tidak yaitu dengan analisis grafik dan uji statistik. Karena analisis grafik dapat menyesatkan, maka dipilih uji statistik Kolmogorov-Smirnov dengan melihat tingkat signifikansinya. Uji ini dilakukan sebelum data diolah. Residual dinyatakan terdistribusi normal jika nilai signifikansi Kolmogorov-Smirnov >0,05.

Uji heteroskedastisitas bertujuan untuk menguji apakah dalam model regresi terjadi ketidaksamaan variance dari residual satu pengamatan ke pengamatan lainnya. ${ }^{9}$ Model regresi yang baik adalah yang homoskedastisitas, yaitu jika variance dari residual satu pengamatan ke pengamatan lainnya tetap. Uji heteroskedastisitas dapat dilakukan dengan uji grafik plot dan uji statistik. Uji statistik Glejser dipilih karena lebih dapat menjamin keakuratan hasil dibandingkan dengan uji grafik plot yang dapat menimbulkan bias. Uji Glejser dilakukan dengan meregresikan variabel bebas terhadap nilai absolute residualnya. ${ }^{10}$ Interpretasi heteroskedastisitas dilakukan dengan melihat signifikansi ROA dan EMV terhadap nilai absolute residual. Gangguan

\footnotetext{
${ }^{8}$ Imam Ghozali, Aplikasi Analisis Multivariate dengan Program IBM SPSS 19, Semarang: Badan Penerbit Universitas Diponegoro, 2011, hlm. 160-163

${ }^{9}$ Ibid, hlm. 139

${ }_{10}$ Damodar Gujarati, Ekonometrika Dasar, Jakarta: Erlangga, 1999, hlm. 187
} 
heteroskedastisitas terjadi jika terdapat pengaruh yang signifikan antara ROA terhadap absolute residualnya. Apabila tingkat probabilitas signifikansi ROA dan EMV $<0.05$, maka dapat dikatakan mengandung heteroskedastisitas.

Uji Autokorelasi dilakukan untuk menguji apakah di dalam suatu model regresi linier terdapat korelasi antara kesalahan pengganggu pada periode $t$ dengan kesalahan pengganggu pada periode t-1. ${ }^{11}$ Pendeteksian ada atau tidaknya autokorelasi menggunakan uji Durbin-Watson. Jumlah emiten sebanyak 21, dan jumlah variabel independen $\mathrm{k}=3$. Jumlah $\mathrm{n}$ yang akan digunakan adalah $\mathrm{n}=63$. Nilai $\mathrm{dl}$ dan du jika dilihat pada tabel DW, tingkat signifikansi 0,05 adalah 1,527 dan 1,658.

Uji multikolinearitas bertujuan untuk menguji apakah dalam model regresi ditemukan adanya korelasi antar variabel bebas. ${ }^{12}$ Untuk menguji multikolinearitas dengan cara melihat nilai VIF masing-masing variabel independen, jika nilai VIF $<10$ dan nilai tolerance $>0,1$, maka dapat disimpulkan data bebas dari gejala multikolinearitas. Model persamaan regresi yang akan diuji adalah sebagai berikut:

Tobin's Q = a + b1 ROA + b2 EMV + e

$$
\begin{aligned}
& \text { Dimana : } \\
& \begin{array}{l}
\text { Tobin's Q } \quad=\text { Nilai Emiten } \\
\begin{array}{l}
\text { a Konstanta } \\
\text { b1, b2 }=\text { Koefisien Regresi }
\end{array} \\
\text { ROA }=\text { Nilai buku dari total ekuitas } \\
\text { EMV }=\text { Kapitalisasi Pasar }
\end{array}
\end{aligned}
$$

Menurut Ghozali, ketepatan fungsi regresi tersebut dalam menaksir nilai aktual dapat diukur dari goodness of fit-nya, yang secara statistik dapat diukur dari koefisien determinasi, nilai statistik F, dan nilai statistik t. ${ }^{13}$ Koefisien determinasi merupakan ikhtisar yang menyatakan seberapa baik garis regresi mencocokkan data. ${ }^{14}$ Nilai $\mathrm{R}^{2}$ berkisar antara $0-1$. Nilai yang kecil

\footnotetext{
11 Ibid, hlm. 110

${ }^{12}$ Ghozali, Aplikasi..., hlm. 105-106

${ }^{13}$ Ibid, hlm. 97

${ }^{14}$ Ibid
}

Volume VI/Edisi 2/Oktober 2015 
Pengaruh Profitabliitas dan Kapitalisasi Pasar...

berarti kemampuan variabel independen dalam menjelaskan variasi variabel dependen amat terbatas. Sebaliknya, nilai yang mendekati satu berarti variabelvariabel independen memberikan hampir semua informasi yang dibutuhkan untuk memprediksi variasi variabel dependen.

Uji statistik F menunjukkan apakah variabel independen yang dimasukkan dalam model mempunyai pengaruh terhadap variabel dependennya. Kriteria pengambilan keputusannya, yaitu, bila $\mathrm{F}$ hitung $>\mathrm{F}$ tabel atau probabilitas $<$ nilai signifikan ( $\operatorname{Sig} \leq 0,05)$,maka hipotesis tidak dapat ditolak, ini berarti bahwa secara simultan variabel independen memiliki pengaruh signifikan terhadap variabel dependen. Sedangkan bila F hitung $<$ F tabel atau probabilitas $>$ nilai signifikan ( $\operatorname{Sig} \geq 0,05)$, maka hipotesis diterima, ini berarti bahwa secara simultan variabel independen tidak mempunyai pengaruh signifikan terhadap variabel dependen.

Uji statistik $\mathrm{t}$ menunjukkan seberapa jauh pengaruh masing-masing variabel independen secara individu dalam menerangkan variasi variabel dependen. Pada uji statistik t, nilai t hitung akan dibandingkan dengan nilai t tabel, dilakukan dengan cara sebagai berikut. Bila $\mathrm{t}$ hitung $>\mathrm{t}$ tabel atau probabilitas < tingkat signifikansi (Sig < 0,05), maka Ha diterima dan Ho ditolak, variabel independen berpengaruh terhadap variabel dependen. Bila t hitung $<\mathrm{t}$ tabel atau probabilitas $>$ tingkat signifikansi (Sig $>$ 0,05), maka $\mathrm{Ha}$ ditolak dan Ho diterima, variabel independen tidak berpengaruh terhadap variabel dependen.

\section{Hasil dan Pembahasan}

Sampel awal yang diperoleh berjumlah 90 perusahaan, namun setelah diseleksi berdasarkan kriteria yang ditetapkan maka diperoleh sampel akhir sebanyak 21 perusahaan. Laporan keuangan yang digunakan adalah periode akhir tahun, karena laporan inilah yang biasanya digunakan untuk pengambilan keputusan strategis oleh para investor.

Tabel 4.1

Sampel Penelitian

Kriteria Sampel

Jumlah 


\begin{tabular}{|l|c|}
\hline Perusahaan yang terdaftar JII priode Desember 2012-2014 & 90 \\
\hline $\begin{array}{l}\text { Perusahaan yang terdaftar secara terus-menerusJII priode } \\
\text { Desember 2012-2014 }\end{array}$ & 21 \\
\hline $\begin{array}{l}\text { Tidak tersedia laporan keuangan pada akhir tahun 2012, 2013, } \\
\text { an1 1 }\end{array}$ & 21 \\
\hline $\begin{array}{l}\text { Tersedia laporan keuangan lengkap pada akhir tahun 2012, 2013, } \\
\text { Tn1 } 1 \text { memiliki data yang lengkap terkait dengan variabel- } \\
\text { variabel yang digunakan dalam penelitian }\end{array}$ & $(0)$ \\
\hline Perusahaan yang memenuhi syarat & 21 \\
\hline Pengamatan selama 3 tahun, periode 2012-2014 (21x3) & 63 \\
\hline
\end{tabular}

Sumber: Data sekunder yang diolah, 2015

Data keuangan diperoleh melalui laporan keuangan dari perusahaan sampel selama tahun 2012-2014, sehingga dilakukan 63 observasi. Perusahaan yang menjadi sampel penelitian dapat dilihat dalam tabel berikut.

Tabel 4.2

Data Perusahaan yang menjadi Sampel Penelitian

\begin{tabular}{|l|l|l|}
\hline No & Nama Perusahaan & Kode \\
\hline 1 & PT. Astra Agro Lestari Tbk & AALI \\
\hline 2 & PT. Adaro Energy Tbk & ADRO \\
\hline 3 & PT. AKR Corporindo Tbk & AKRA \\
\hline 4 & PT. Astra International Tbk & ASII \\
\hline 5 & PT. Indofood CBP Sukses Makmur Tbk & ICBP \\
\hline 6 & PT. Indofood Sukses Makmur Tbk & INDF \\
\hline 7 & PT. Indocement Tunggal Prakasa Tbk & INTP \\
\hline 8 & PT. Indo Tambangraya Megah Tbk & ITMG \\
\hline 9 & PT. PP London Sumatera Plantation Tbk & LSIP \\
\hline 10 & PT. Perusahaan Gas Negara (Persero) Tbk & PGAS \\
\hline 11 & PT. Semen Indonesia (Persero) Tbk & SMGR \\
\hline 12 & PT. Telekomunikasi Indonesia (Persero) Tbk & TLKM \\
\hline 13 & PT. United Tractors Tbk & UNTR \\
\hline 14 & PT. Alam Sutera Realty Tbk & ASRI \\
\hline 15 & PT. Bumi Serpong Damai Tbk & BSDE \\
\hline 16 & PT. Charoen Pokhpand Tbk & CPIN \\
\hline 17 & PT. Kalbe Farma Tbk & KLBF \\
\hline 18 & PT. Lippo Karawaci Tbk & MNCN \\
\hline 19 & PT. Media Nusantara Citra Tbk & \\
\hline
\end{tabular}


Pengaruh Profitabliitas dan Kapitalisasi Pasar...

\begin{tabular}{|c|l|c|}
\hline 20 & $\begin{array}{l}\text { PT. Tambang Batubara Bukit Asam (Persero) } \\
\text { Tbk }\end{array}$ & PTBA \\
\hline 21 & PT. Unilever Indonesia Tbk & UNVR \\
\hline
\end{tabular}

Sumber : Data IDX 2015

Pengujian normalitas mengggunakan Uji Kolmogorov-Smirnov menunjukkan nilai Kolmogorov-Smirnov untuk variabel Tobin's Q sebesar 2,177 dengan Asymted Sig. (2-tailed) 0,000 yang artinya distribusi datanya tidak normal. Sedangkan untuk variabel ROA dan EMV distribusinya normal karena Asymted Sig. (2-tailed) berada diatas 0,05. Untuk mengatasi masalah ini dilakukan dengan me-log linear-kan datanya terlebih dahulu sebelum diregresi. Setelah di-log linier-kan datanya, hasil uji Kolmogorov-Smirnov pada Tabel 4.3 menunjukkan Asymted Sig. (2-tailed) berada di atas 0,05 semuanya, yaitu 0,604 untuk LNROA, 0,991 untuk LEMV, dan 0,516 untuk LNQ yang artinya semua data distribusinya telah normal.

Tabel 4.3

\section{Hasil Uji Normalitas}

One-Sample Kolmogorov-Smirnov Test

\begin{tabular}{|c|c|c|c|c|}
\hline & & $\begin{array}{l}\text { LNR } \\
\text { OA }\end{array}$ & $\begin{array}{l}\mathrm{LN} \\
\mathrm{Q}\end{array}$ & $\begin{array}{l}\text { LNE } \\
\text { MV }\end{array}$ \\
\hline \multicolumn{2}{|l|}{$\overline{\mathrm{N}}$} & 63 & 63 & 63 \\
\hline \multirow{5}{*}{$\begin{array}{l}\text { Normal } \\
\text { Parameters }\end{array}$} & Mean & & 8995 & 31,5 \\
\hline & & 1,83 & & 524 \\
\hline & & 97 & & \\
\hline & Std. Deviation & ,577 & ,6250 & ,902 \\
\hline & & 33 & & 81 \\
\hline Most Extreme & Absolute & ,096 & 103 & 055 \\
\hline \multirow[t]{2}{*}{ Differences } & Positive & 080 & 103 & 055 \\
\hline & Negative &,- 096 &,- 082 &,- 050 \\
\hline \multicolumn{2}{|c|}{ Kolmogorov-Smirnov Z } &, 764 & 817 & 435 \\
\hline \multicolumn{2}{|l|}{ Asymp. Sig. (2-tailed) } & 604 &, 516 & ,991 \\
\hline
\end{tabular}

a. Test distribution is Normal.

b. Calculated from data.

Dari hasil Uji Glejser pada Tabel 4.4 diperoleh nilai signifikansi dari LNROA sebesar 0,152, dan LNEMV sebesar 0,215. Apabila tingkat 
probabilitas signifikansi LNROA dan LNEMV $<0,05$, maka dapat dikatakan mengandung heteroskedastisitas, Jadi dapat disimpulkan bahwa data residual tidak terjadi heteroskedastisitas.

Tabel 4.4

Hasil Uji Glejser

Coefficients $^{\mathrm{a}}$

\begin{tabular}{|c|c|c|c|c|c|c|}
\hline \multirow{2}{*}{\multicolumn{2}{|c|}{ Model }} & \multicolumn{2}{|c|}{$\begin{array}{l}\text { Unstandardized } \\
\text { Coefficients }\end{array}$} & \multirow{2}{*}{$\begin{array}{c}\text { Standardi } \\
\text { zed } \\
\text { Coefficie } \\
\text { nts }\end{array}$} & \multirow[b]{2}{*}{ t } & \multirow[b]{2}{*}{ Sig. } \\
\hline & & B & $\begin{array}{l}\text { Std. } \\
\text { Error }\end{array}$ & & & \\
\hline 1 & $\begin{array}{c}\text { (Const } \\
\text { ant) }\end{array}$ &,- 881 & 1,092 & &,- 807 & ,423 \\
\hline & $\begin{array}{c}\mathrm{LNRO} \\
\mathrm{A}\end{array}$ & 075 & ,052 & ,200 & 1,453 & ,152 \\
\hline & $\begin{array}{l}\text { LNE } \\
\text { MV }\end{array}$ & 041 & ,033 & ,173 & 1,252 & ,215 \\
\hline
\end{tabular}

a. Dependent Variable: ABSRESIDUAL

Dari Uji Autikorelasi pada Tabel 4.5 didapat nilai Durbin Watson sebesar 1,894. Sedangkan nilai $d u$ yang didapat dari tabel signifikansi $5 \%$ dengan jumlah variabel independen $2(K=2)$ sebesar 1,658. Nilai Durbin Watson sebesar 1,894 lebih besar dari batas atas (du) yakni 1,658 dan kurang dari 4 - $d u, 4-1,658=2,342$ menunjukkan bahwa tidak terdapat autokorelasi.

Tabel 4.5

Hasil Uji Autokorelasi

Model Summary ${ }^{\mathrm{b}}$

\begin{tabular}{|l|l|l|l|l|l|}
\hline $\begin{array}{l}\mathrm{M} \\
\mathrm{od} \\
\mathrm{el}\end{array}$ & $\mathrm{R}$ & $\begin{array}{l}\mathrm{R} \\
\text { Squar } \\
\mathrm{e}\end{array}$ & $\begin{array}{l}\text { Adjusted } \\
\text { R Square }\end{array}$ & $\begin{array}{l}\text { Std. Error } \\
\text { of the } \\
\text { Estimate }\end{array}$ & $\begin{array}{l}\text { Durbin- } \\
\text { Watson }\end{array}$ \\
\hline 1 &, $815^{\mathrm{a}}$ &, 665 &, 653 &, 36799 & 1,894 \\
\hline
\end{tabular}

a. Predictors: (Constant), LNEMV, LNROA

b. Dependent Variable: LNQ 
Pengaruh Profitabliitas dan Kapitalisasi Pasar...

Dari hasil Uji Multikolineritas pada Tabel 4.6 diperoleh nila VIF baik LNROA maupun LNEMV sebesar 1,272, kemudian nilai Tolerance baik LNROA maupun LNEMV sebesar 0,786. Sehingga dapat disimpulkan bahwa tidak terjadi Multikolinearitas antar variabel independen dalam model regresi karena nilai Tolerance $>0.1$ dan nilai $\mathrm{VIF}<10$.

Tabel 4.6

Hasil Uji Multikolinieritas

\begin{tabular}{|ll|l|l|}
\hline \multicolumn{2}{|c|}{ Coefficients $^{\mathrm{a}}$} & \multicolumn{2}{|l|}{ Collinearity } \\
& & \multicolumn{2}{|l|}{ Statistiks } \\
\cline { 3 - 4 } Model & Tolera & VI \\
& & nce & F \\
\hline 1 & LNROA &, 786 & 1,2 \\
& & & 72 \\
& &, 786 & 1,2 \\
& LNEMV &, 72 \\
\hline
\end{tabular}

a. Dependent Variable: LNQ

Nilai Koefisien Determinasi pada Tabel 4.7 sebesar 0,653 menunjukkan bahwa model regresinya sudah baik karena kemampuan variabel bebas menjelaskan variabel terikat sebesar 65,3\%. Sisanya sebesar 34,7\% dijelaskan oleh variabel lain di luar penelitian.

Tabel 4.7

Hasil Uji Kelayakan Model

Model Summary

\begin{tabular}{|l|l|l|l|l|}
\hline $\begin{array}{l}\mathrm{M} \\
\text { od } \\
\mathrm{el}\end{array}$ & $\mathrm{R}$ & $\begin{array}{l}\mathrm{R} \\
\text { Squar } \\
\mathrm{e}\end{array}$ & $\begin{array}{l}\text { Adjusted } \\
\text { R Square }\end{array}$ & $\begin{array}{l}\text { Std. } \\
\text { Error of } \\
\text { the } \\
\text { Estimate }\end{array}$ \\
\hline 1 &, $815^{\mathrm{a}}$ &, 665 &, 653 &, 36799 \\
\hline
\end{tabular}

a. Predictors: (Constant), LNEMV, LNROA 
Hasil Uji Statistik t pada Tabel 4.8 menunjukkan bahwa nilai signifikansi LNROA sebesar 0,000 dan LNEMV sebesar 0,195. Nilai signifikansi LNROA sebesar 0,000 lebih kecil dari 0,05 artinya secara parsial ROA berpengaruh siginifikan terhadap nilai emiten. Sedangkan nilai signifikansi LNEMV sebesar 0,195 lebih besar dari 0,05 artinya secara parsial EMV tidak berpengaruh siginifikan terhadap nilai emiten.

Tabel 4.8

Hasil Uji Statistik t

Coefficients $^{\mathrm{a}}$

\begin{tabular}{|c|c|c|c|c|c|c|}
\hline \multirow{2}{*}{\multicolumn{2}{|c|}{ Model }} & \multicolumn{2}{|c|}{$\begin{array}{l}\text { Unstandardized } \\
\text { Coefficients }\end{array}$} & \multirow{2}{*}{$\begin{array}{l}\text { Standardi } \\
\text { zed } \\
\text { Coefficie } \\
\text { nts } \\
\text { Beta }\end{array}$} & \multirow[b]{2}{*}{$\mathrm{t}$} & \multirow[b]{2}{*}{ Sig. } \\
\hline & & B & $\begin{array}{l}\text { Std. } \\
\text { Error }\end{array}$ & & & \\
\hline \multirow[t]{3}{*}{1} & $\begin{array}{l}\text { (Const } \\
\text { ant) }\end{array}$ &,- 004 & 1,926 & &,- 002 & ,998 \\
\hline & $\begin{array}{l}\text { LNRO } \\
\text { A }\end{array}$ & ,821 & 091 & ,758 & 8,989 & ,000 \\
\hline & $\begin{array}{l}\text { LNE } \\
\text { MV }\end{array}$ & ,076 & ,058 & ,110 & 1,310 & 195 \\
\hline
\end{tabular}

a. Dependent Variable: LNQ

Hasil Uji Statistik F pada Tabel 4.9 diperoleh nilai signifikansi sebesar 0,000 lebih kecil dari 0,05, artinya secara simultan, profitabilitas dan kapitalisasi pasar berpengaruh signifikan terhadap nilai emiten.

Tabel 4.9

Hasil Uji Statistik F

ANOVA $^{\mathrm{b}}$

\begin{tabular}{|c|c|c|c|c|c|c|}
\hline \multicolumn{2}{|c|}{ Model } & $\begin{array}{l}\text { Sum of } \\
\text { Squares }\end{array}$ & $\mathrm{df}$ & $\begin{array}{l}\text { Mean } \\
\text { Square }\end{array}$ & $\mathrm{F}$ & Sig. \\
\hline 1 & $\begin{array}{l}\text { Regress } \\
\text { ion }\end{array}$ & 16,094 & 2 & 8,047 & $\begin{array}{l}59,42 \\
6\end{array}$ &, $000^{a}$ \\
\hline & Residua & 8,125 & 60 & ,135 & & \\
\hline & Total & 24,219 & 62 & & & \\
\hline
\end{tabular}

Volume VI/Edisi 2/Oktober 2015 
Pengaruh Profitabliitas dan Kapitalisasi Pasar...

ANOVA $^{\mathrm{b}}$

\begin{tabular}{|c|c|c|c|c|c|c|}
\hline \multicolumn{2}{|c|}{ Model } & $\begin{array}{l}\text { Sum of } \\
\text { Squares }\end{array}$ & $\mathrm{df}$ & $\begin{array}{l}\text { Mean } \\
\text { Square }\end{array}$ & \multirow{2}{*}{ 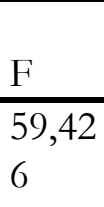 } & \multirow{2}{*}{$\frac{\text { Sig. }}{, 000^{a}}$} \\
\hline 1 & $\begin{array}{l}\text { Regress } \\
\text { ion }\end{array}$ & 16,094 & 2 & 8,047 & & \\
\hline & $\begin{array}{l}\text { Residua } \\
1\end{array}$ & 8,125 & 60 & ,135 & & \\
\hline & Total & 24,219 & 62 & & & \\
\hline
\end{tabular}

a. Predictors: (Constant), LNEMV, LNROA

b. Dependent Variable: LNQ

\section{Penutup}

Berdasarkan hasil analisis terhadap 21 perusahaan sampel dari tahun 2012-2014 dalam penelitian ini, maka dapat disimpulkan bahwa profitabilitas berpengaruh signifikan terhadap nilai emiten. Hal ini ditunjukkan dengan taraf signifikansi dari hasil uji statistik $\mathrm{t}$ sebesar $0,000 \quad(<0,05)$. Sedangkan kapitalisasi pasar tidak berpengaruh secara signifikan terhadap nilai emiten yang ditunjukkan dengan taraf signifikansi sebesar 0,195 (>0,05).Namun secara simultan profitabilitas dan kapitalisasi pasar berpengaruh signifikan terhadap nilai emiten. Hal ini diketahui dari hasil uji statistik $F$, taraf signifikansinya sebesar $0,000(<0,05)$.

Nilai Koefisien Determinasi sebesar 0,653 menunjukkan bahwa model regresinya sudah baik karena kemampuan variabel bebas menjelaskan variabel terikatnya sebesar 65,3\%. Sisanya sebesar 34,7\% dijelaskan oleh variabel di luar penelitian.Penelitian ini memiliki beberapa keterbatasan diantaranya adalah perusahaan yang menjadi sampel penelitian hanya dari perusahaan yang terus menerus masuk Indeks JII berjumlah 21 perusahaan dari tahun 2012-2014, hanya menggunakan ROA sebagai proksi dari profitabilitas.

Berdasarkan hasil analisis pembahasan serta beberapa kesimpulan dan keterbatasan pada penelitian ini, maka saran-saran yang dapat diberikan dari hasil penelitian ini, yaitu: penelitian selanjutnya hendaknya melakukan analisis fundamental yang lebih lengkap, tidak hanya memakai rasio profitabilitas saja sebagai variabel independennya, tetapi juga rasio likuiditas, rasio aktivitas, dan rasio leverage. Penelitian selanjutnya hendaknya melakukan analisis teknikal yang 
lebih lengkap tidak hanya menggunakan kapitalisasi pasar sebagai variabel independennya, tetapi juga data historis saham, volume perdagangan saham, dan trend harga saham. Penelitian selanjutnya diharapkan menggunakan seluruh perusahaan yang tergabung dalam ISSI (Indeks Saham Syariah Indonesia), dengan sampel yang lebih banyak dan tahun pengamatan yang lebih lama membuat kemungkinan bias penelitian menjadi lebih kecil. 
Pengaruh Profitabliitas dan Kapitalisasi Pasar...

\section{DAFTAR PUSTAKA}

Fauzi, A. dkk., Aplikasi Excel dalam Finansial Terapan, Jakarta: PT.ELex Media Komputindo, 2004.

Ghozali, Imam, Aplikasi Analisis Multivariate dengan Program IBM SPSS 19, Semarang: Badan Penerbit Universitas Diponegoro, 2011.

Gujarati, Damodar, Ekonometrika Dasar, Jakarta: Erlangga, 1999.

Jumingan, Analisis Laporan Kenangan, Jakarta: Bumi Aksara, 2005.

Lewellen, W.G. dan S.G. Badrinath, "On the Measurement of Tobin's q," Journal of Financial Economics, April 1997, p. 77-122.

Michell Suharli, "Studi Empiris terhadap Faktor yang Mempengaruhi Nilai emiten pada Perusahaan Go Public di Indonesia", Jurnal Maksi, Volume 6, Nomor 1, Januari 2002. h. 23-41.

Nurlela, Rika dan Islahudin, "Pengaruh Corporate Social Responsibility terhadap Nilai emiten dengan Prosentase Kepemilikan Manajemen sebagai Variabel Moderating", Simposium Nasional Akuntansi XI Pontianak, 2008, h. 7.

Rahardjo, Sapto, Kiat Membangun Aset Kekayaan, Jakarta: PT. Elex Media Komputindo, 2006.

Vinolla Herawaty,. "Peran Praktek Corporate Governance sebagai Moderating Variable dari Pengaruh Earnings Management terhadap Nilai emiten" Jurnal Akuntansi dan Keuangan, Vol. 10, No. 2, 2008, h. 97-108. 